\title{
Improved Corrosion Resistance in AZ61 Magnesium Alloys Induced by Impurity Reduction
}

\author{
Yan Dai ${ }^{1} \cdot$ Xian-Hua Chen ${ }^{1,2} \cdot$ Tao Yan $^{1} \cdot$ Ai-Tao Tang ${ }^{1,2} \cdot$ Di Zhao $^{1} \cdot$ Zhu Luo $^{1} \cdot$ Chun-Quan Liu ${ }^{1} \cdot$ Ren-Ju Cheng ${ }^{2}$. \\ Fu-Sheng Pan ${ }^{1,2}$
}

Received: 22 February 2019 / Revised: 25 March 2019 / Published online: 14 May 2019

(C) The Chinese Society for Metals (CSM) and Springer-Verlag GmbH Germany, part of Springer Nature 2019

\begin{abstract}
The effect of impurity element Fe on corrosion behavior of AZ61 magnesium alloys in various states has been investigated by immersion test and hydrogen evolution measurements in 3.5\% sodium chloride solution. The corrosion rate is found to relay on the impurity Fe concentration in the alloys and decreases with decreasing Fe content. When Fe content drops from $150 \mathrm{ppm}$ to $10 \mathrm{ppm}$, the corresponding corrosion rates under as-cast and solution treatment conditions are reduced from $8.54 \mathrm{~mm} / \mathrm{a}$ and $8.61 \mathrm{~mm} / \mathrm{a}$ to $2.54 \mathrm{~mm} / \mathrm{a}$ and $0.21 \mathrm{~mm} / \mathrm{a}$, respectively. The corrosion pattern of the AZ61 alloys is the localized corrosion, and the galvanic couples are formed among the impurity particles, second-phase particles and the matrix. The Fe impurity particles tend to act as main cathodic to form micro-galvanic cell with the $\alpha$-Mg matrix, which is harmful for corrosion resistance of AZ61 alloy.
\end{abstract}

Keywords AZ61 magnesium alloy $\cdot$ Impurity $\mathrm{Fe} \cdot$ Corrosion rate

\section{Introduction}

The demand for applications of magnesium alloys in automobiles and structural fields is continuously increasing due to their low density and high strength-to-weight ratio [1-7]. However, their low corrosion resistance limits their practical applications, and their corrosion rates are usually high in most inorganic acidic and neutral solutions [8-13]. Poor corrosion resistance is due to high inherent solubility tendency. The protective oxide film can partially cover the alloy surface and corrode at the break of the film [14-18]. Moreover, it was reported that the presence of detrimental elements ( $\mathrm{Fe}, \mathrm{Ni}, \mathrm{Cu}$ and $\mathrm{Co}$ ) with high standard electrode potential and second phases act as local cathodes cause local galvanic acceleration of corrosion [19-27]. Among these impurity elements, even a small amount of Fe may

Available online at http://link.springer.com/journal/40195

Xian-Hua Chen

xhchen@cqu.edu.cn

1 College of Materials Science and Engineering, Chongqing University, Chongqing 400045, China

2 Chongqing Academy of Science and Technology, Chongqing 401123, China severely deteriorate the corrosion resistance of magnesium alloys [28-32]. Matsubara et al. [4] studied the effect of Fe content on corrosion rate of AM60/50; they pointed out that inclusions with high Fe content were the preferential initiation points for corrosion, and as the $\mathrm{Fe} / \mathrm{Mn}$ ratio decreased slightly, the corrosion rate decreased by orders of magnitude. Liu et al. [16, 33] and Inoue et al. [23] reported that the corrosion rate of magnesium alloy was substantially high due to its contamination with $\mathrm{Fe}$ above the tolerance limit. It has been reported that if the iron content of the magnesium alloy is less than $20 \mathrm{ppm}$, the corrosion resistance of magnesium alloys may be lower than the corrosion resistance of aluminum alloys [34]. Liu et al. [16, 33] theoretically explained the corrosion tolerance limit of $170 \mathrm{ppm}$ for Fe through the $\mathrm{Mg}-\mathrm{Fe}$ phase diagram, and the corrosion tolerance limit of Fe can be significantly reduced to about $5-10 \mathrm{ppm}$ after heat treatment $[21,33,35]$. There are two hypotheses for the tolerance limits of impurities ( $\mathrm{Fe}, \mathrm{Ni}$ and $\mathrm{Cu}$ ) in $\mathrm{Mg}$ alloys: (1) phase precipitation; (2) surface deposition [22].

Researches have been carried out about the relationship between microstructure and corrosion for $\mathrm{Mg}-\mathrm{Al}-\mathrm{Zn}(\mathrm{AZ})$ alloys [36-40]. Many researchers have predicted that magnesium alloys containing very low level of Fe have good corrosion resistance, but few experimental studies have reported the corrosion properties of magnesium alloys containing $\mathrm{Fe}$ 
content less than $15 \mathrm{ppm}$. According to the existing literature reports [41, 42], the content of impurity $\mathrm{Fe}$ can be controlled by the melting process. In this present study, AZ61 alloys with $\mathrm{Fe}$ content from 10 to $150 \mathrm{ppm}$ were prepared by melt purification treatment, and their microstructure and corrosion behavior in different heat treatment conditions were investigated in detail. Such an investigation may provide an important basis for the development of high corrosion resistance magnesium alloys.

\section{Experimental}

In order to understand the impurity precipitation process, $\mathrm{Mg}$ phase diagrams were calculated using the PANDAT software package (database PanMg_2013_MB) [43].

Four AZ61 alloys with different Fe contents were used in the present study. The pre-alloyed AZ61 magnesium alloy ingots were melted in a stainless-steel crucible $(\Phi 90 \mathrm{~mm} \times 280 \mathrm{~mm})$ using a resistance furnace. The $\mathrm{Fe}$ concentration in samples was controlled by equilibrating the melt at different nominal lower temperatures. When the temperature reached $750{ }^{\circ} \mathrm{C}$, the alloy melt was stirred for $5 \mathrm{~min}$ and subsequently held at $750{ }^{\circ} \mathrm{C}$ for $10 \mathrm{~min}$, and subsequently held at $710^{\circ} \mathrm{C}$ for $45 \mathrm{~min}$, then cooled to relative low temperature of $630{ }^{\circ} \mathrm{C}$ for $0,30,45$ and $60 \mathrm{~min}$, corresponding to alloy A, B, C and D, respectively. The impurity Fe particles in the melt would have different degrees of sedimentation with different holding times to control the content of Fe impurities in AZ61 alloys. The alloy melt then was cooled to solidify by water cooling. The actual chemical compositions of the alloys were analyzed by inductively coupled plasma-emission spectrometry (ICP, Optima 8300), and their corresponding compositions are listed in Table 1. Solution treatment (T4) was held at $400{ }^{\circ} \mathrm{C}$ for $24 \mathrm{~h}$ in an air atmosphere followed by quenching into cold water, and aging treatment (T6) was held at $200{ }^{\circ} \mathrm{C}$ for $12 \mathrm{~h}$.

For the microstructure observation, the samples were mechanically polished using $1-\mu \mathrm{m}$ diamond paste, etching with a mixture of $5 \mathrm{~g}$ picric acid, $100 \mathrm{~mL}$ ethanol, $10 \mathrm{~mL}$ acetic acid and $10 \mathrm{~mL}$ distilled water. Microstructures of these alloys were observed using scanning electron microscopy (SEM, TESCAN VEGA III LMH) with energy-dispersive spectrometer (EDS).

Table 1 Chemical compositions of AZ61 alloys

\begin{tabular}{llllll}
\hline Alloy & $\mathrm{Al}(\mathrm{wt} \%)$ & $\mathrm{Zn}(\mathrm{wt} \%)$ & $\mathrm{Fe}(\mathrm{ppm})$ & $\mathrm{Mn}(\mathrm{wt} \%)$ & $\mathrm{Mg}(\mathrm{wt} \%)$ \\
\hline A & 7.44 & 0.71 & 150 & 0.17 & Bal. \\
B & 7.45 & 0.65 & 80 & 0.18 & Bal. \\
C & 7.52 & 0.70 & 20 & 0.14 & Bal. \\
D & 7.39 & 0.65 & 10 & 0.13 & Bal. \\
\hline
\end{tabular}

The specimens for weight loss and hydrogen gas collection to characterize corrosion rate were cut in the mid-portion of the alloy ingots individually. The dimension of the specimens for both tests was $10 \mathrm{~mm} \times 10 \mathrm{~mm} \times 10 \mathrm{~mm}$ and encapsulated in epoxy resin so that a surface area of $1 \mathrm{~cm}^{2}$ was exposed to the $3.5 \% \mathrm{NaCl}$ solution. The weight loss rate $\Delta W\left(\mathrm{mg} /\left(\mathrm{cm}^{2} \mathrm{~d}\right)\right)$ can be converted to an average corrosion rate, $P_{\mathrm{W}},(\mathrm{mm} / \mathrm{a})$ as follows [44]:

$P_{\mathrm{W}}=2.10 \Delta W$.

The hydrogen evolution rate, $V_{\mathrm{H}}\left(\mathrm{ml} /\left(\mathrm{cm}^{2} \mathrm{~d}\right)\right)$, is related to the metallic weight loss, $\Delta W\left(\mathrm{mg} /\left(\mathrm{cm}^{2} \mathrm{~d}\right)\right)$, and the corresponding corrosion rate, $P_{\mathrm{H}}(\mathrm{mm} / \mathrm{a})$ [44]:

$P_{\mathrm{H}}=2.279 V_{\mathrm{H}}$.

After each immersion test, the sample was taken out, and chromic acid solution (consisting of $200 \mathrm{~g} / \mathrm{L} \mathrm{CrO}_{3}$ saturated with $10 \mathrm{~g} / \mathrm{L}_{\mathrm{AgNO}_{3}}$ ) was used as a cleaning solution for removing corrosion products on the surface. The morphology of the corroded samples was examined and recorded using macro-photographs and scanning electron microscopy (SEM) after corrosion product removal.

\section{Results}

\subsection{Microstructure}

The phase calculation results of the investigated AZ61 alloy with 150-ppm Fe content are shown in Fig. 1. According to the calculations, after solidification, AZ61 alloy mainly consists of $\alpha-\mathrm{Mg}, \mathrm{Mg}_{17} \mathrm{Al}_{12}$ and $\mathrm{Al}_{8} \mathrm{Mn}_{5}$. Given that this work was kept at a high temperature of $750{ }^{\circ} \mathrm{C}$ for $10 \mathrm{~min}$, and subsequently held at $710^{\circ} \mathrm{C}$ for $45 \mathrm{~min}$, then cooled to relative low temperature of $630^{\circ} \mathrm{C}$ for $0 \mathrm{~min}$ and then watercooled, so it can be regarded as an equilibrium state at a high temperature, and the cooling process is nonequilibrium state. Therefore, we only considered the high-temperature state of Fig. 1b and the low temperature state of Fig. 1a. Based on the above analysis, as shown in Fig. 1a, we could expect a very small amount of $\mathrm{Fe}$ in alloy $\mathrm{A}$, and Fe particles are precipitated at high temperature as a simple substance. It is interesting to note that, at the equilibrium condition, almost all of the Fe disappears when the $\mathrm{Al}_{8} \mathrm{Mn}_{5}$ phase appears, as shown in Fig. 1b. It also can be evidenced, as discussed later, that $\mathrm{Fe}$ particles are concentrated in the second phase containing $\mathrm{Al}$ and $\mathrm{Mn}$, which decreases $\mathrm{Fe}$ content in the Mg matrix.

Figure 2 displays SEM micrographs of the four studied AZ61 alloys under various states, exhibiting the typical microscopic appearance. Similar microstructure is observed for the four as-cast AZ61 specimens, which has a typical dendritic structure and is characterized by divorced 

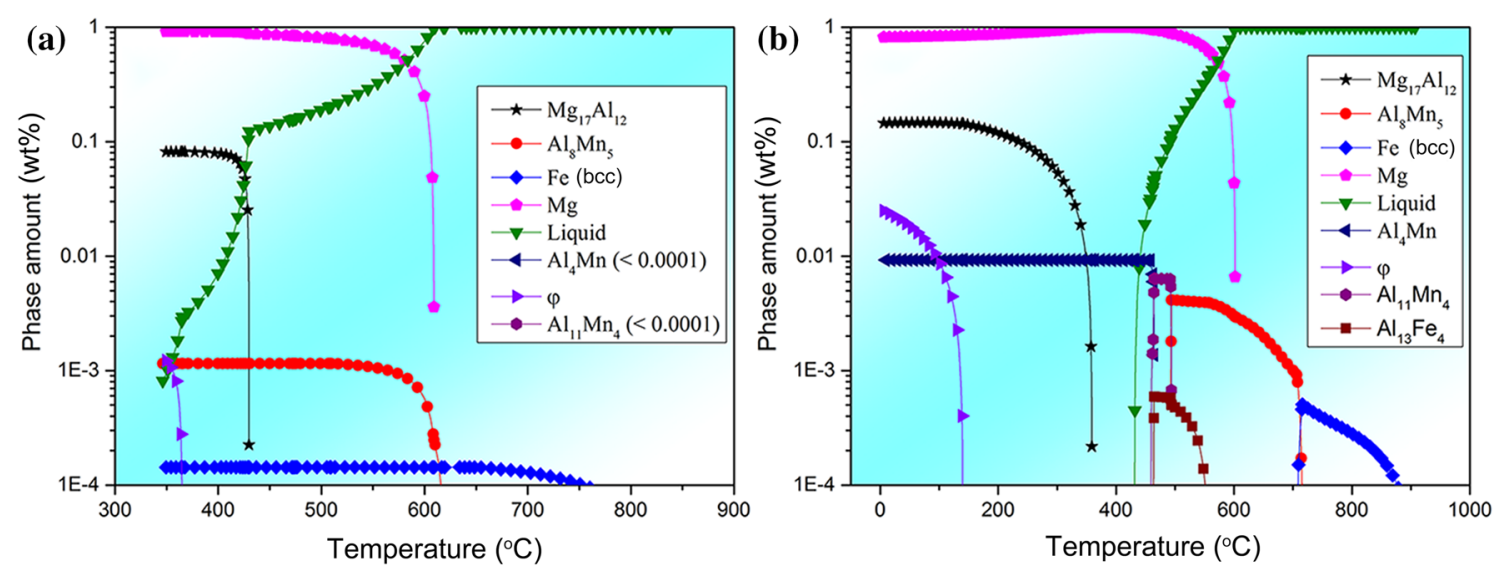

Fig. 1 Phase amounts (mass fraction) calculated with the PANDAT software [43] for different cooling conditions for AZ61 alloy with 150 ppm Fe: a rapid solidification under Scheil condition; $\mathbf{b}$ equilibrium condition ( $b c c$ body-centered cubic)

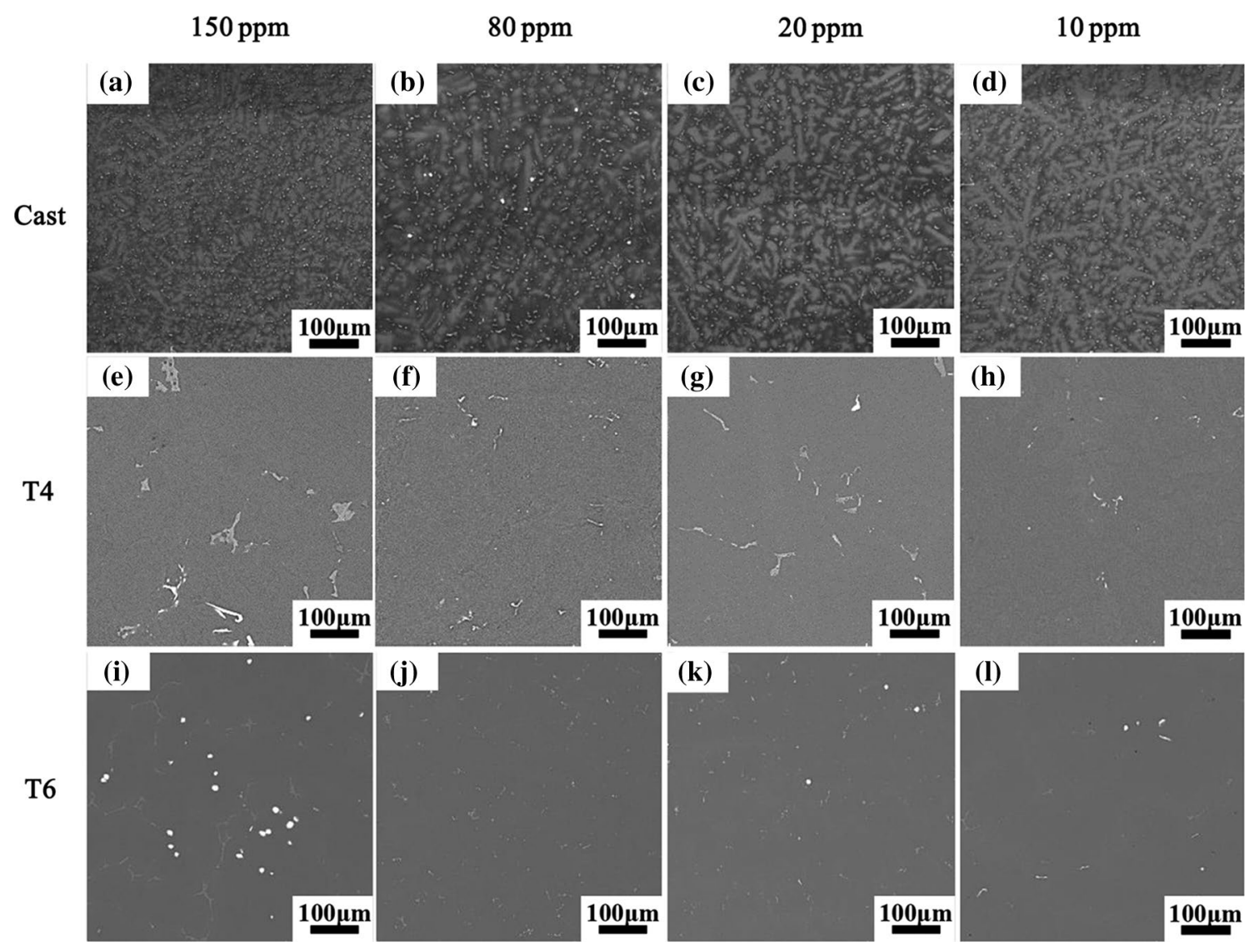

Fig. 2 SEM micrographs of AZ61 alloys with different Fe contents in various states

eutectic as shown in Fig. 2a-d. Obviously, the content of impurity Fe does not remarkably affect the microstructure of the as-cast AZ61 alloy which consists of $\alpha-\mathrm{Mg}$ and discontinuous $\beta$-phase $\left(\mathrm{Mg}_{17} \mathrm{Al}_{12}\right)$. After solution treatment, most of $\beta$-phase precipitates are dissolved into $\alpha-\mathrm{Mg}$ matrix (Fig. 2e-h). After aging at $200{ }^{\circ} \mathrm{C}$ for $12 \mathrm{~h}$, there were obvious precipitation of the second-phase particles around grain boundaries, and the change of the impurity Fe content had little effect on the grain size. According to phase amounts calculated (Fig. 1), the bright phase should be confirmed as $\mathrm{Al}_{8} \mathrm{Mn}_{5}$. 
In order to further analyze the distribution of the elements in the as-cast AZ61 containing 150 ppm Fe, the elements mapping is obtained, which is illustrated in Fig. 3. It is cleared that the white bulk phase is enriched region of $\mathrm{Al}$ and $\mathrm{Mn}$ elements and the discontinuous second phase is $\beta-\mathrm{Mg}_{17} \mathrm{Al}_{12}$. It also can be seen that Fe particles are preferentially enriched in the Al-Mn phase, which is consistent with the calculated results.

\subsection{Corrosion Behavior}

Figure 4 presents the weight loss curve of AZ61 alloys in the cast, solution treatment and aged conditions. The corrosion rates of AZ61 alloys decrease rapidly with the content of Fe impurity, especially for solution treatment. In particular, AZ61-T4 alloy with 10 ppm Fe exhibits the lowest corrosion rate less than $0.21 \mathrm{~mm} / \mathrm{a}$, which represents a relatively high corrosion resistance. In contrast, the corrosion rate of

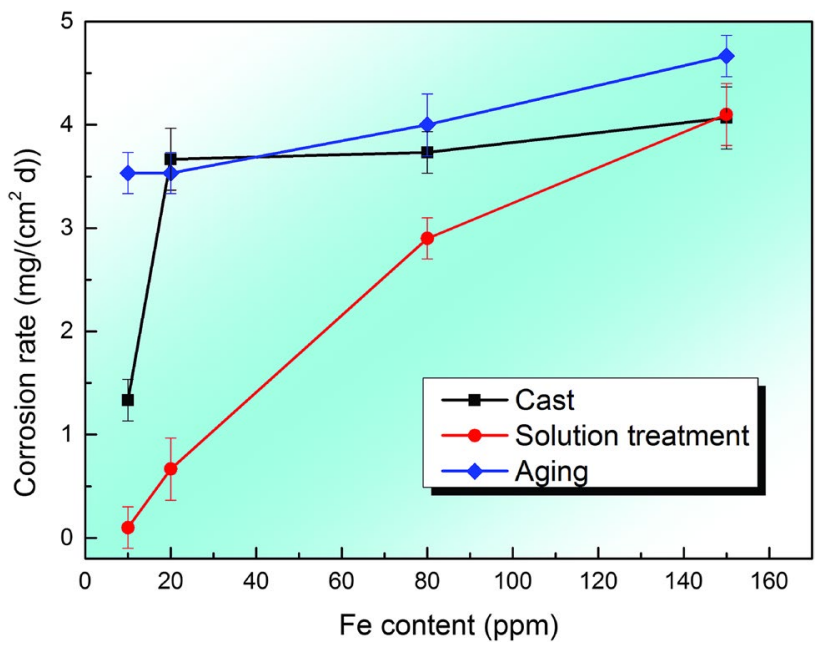

Fig. 4 Corrosion behavior of AZ61 alloys with different Fe contents measured by weight loss for $36 \mathrm{~h}$

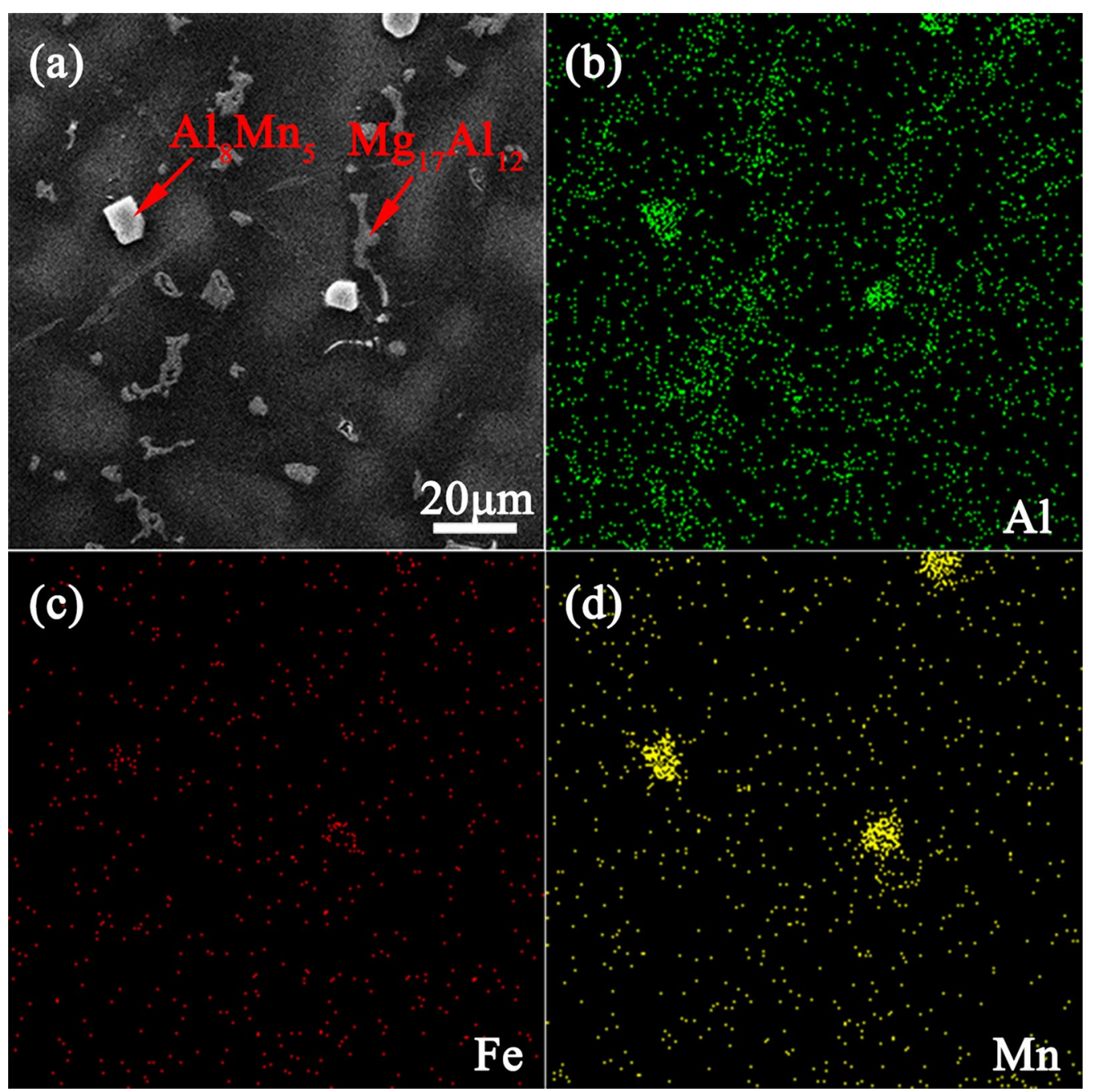

Fig. 3 Microstructure of as-cast AZ61 alloy with 150 ppm Fe a and corresponding EDS chemical maps for Al b, Fe c, Mn d 
AZ61-T4 alloy with $150 \mathrm{ppm} \mathrm{Fe}$ is four times higher than that of the alloy with $10 \mathrm{ppm} F$. The corrosion rates of AZ61 alloy containing $10 \mathrm{ppm} \mathrm{Fe}$ in the as-cast, solution treatment and aging state are significantly different, which were $2.7,0.21$ and $7.3 \mathrm{~mm} / \mathrm{a}$, respectively. As shown in Fig. 4, there is a smaller difference in the corrosion rate between the as-cast and aged condition of the AZ61 alloys having $\mathrm{Fe}$ content of more than $20 \mathrm{ppm}$. The corrosion rate in the aged condition is close to cast condition, but the variation tendency is gently with increasing Fe concentration. Table 2 summarizes the corrosion resistance for some magnesium alloys and aluminum alloy. It is noted that the corrosion rate of AZ61 alloy containing $10 \mathrm{ppm} \mathrm{Fe}$ is significantly lower than that of the conventional magnesium alloys, especially even lower than that of A380 aluminum alloy under the solution condition.

Figure 5 displays the hydrogen evolution curve of AZ61 alloys under different heat treatment conditions immersed for $6.5 \mathrm{~d}$. Most specimens exhibit an increase in hydrogen evolution rate with increasing immersion time. The hydrogen evolution volume of the AZ61 alloy containing $10 \mathrm{ppm}$ of $\mathrm{Fe}$ increases linearly with the exposure time. Hydrogen evolution decreases with decreasing Fe content in all of the

Table 2 Corrosion resistance of magnesium alloys and aluminum alloy

\begin{tabular}{lllll}
\hline Alloy & Fe $(\mathrm{ppm})$ & $\begin{array}{l}\text { Corrosion rate } \\
\left(\mathrm{mg} /\left(\mathrm{cm}^{2} \mathrm{~d}\right)\right)\end{array}$ & $\begin{array}{l}\text { Corrosion } \\
\text { rate }(\mathrm{mm} / \mathrm{a})\end{array}$ & References \\
\hline AZ31 & 50 & 5.5 & 11 & {$[45]$} \\
Mg-9Al & $<100$ & 4.4 & 9.2 & {$[46]$} \\
Mg-3Al-0.2Y & 51 & 0.7 & 1.4 & {$[47]$} \\
AZ91D & 10 & 1.4 & 3 & {$[48]$} \\
A380 & - & 0.28 & 0.59 & {$[49]$} \\
AZ61 & 10 & 1.3 & 2.7 & This work \\
AZ61-T4 & 10 & 0.1 & 0.21 & This work \\
AZ61-T6 & 10 & 3.5 & 7.3 & This work \\
\hline
\end{tabular}

samples. It is observed in Fig. 5 that the corrosion rates of AZ61 alloy with $10 \mathrm{ppm} \mathrm{Fe}$ under as-cast and aged conditions are $0.0326 \mathrm{~mL} /\left(\mathrm{cm}^{2} \mathrm{~h}\right)$ and $0.0286 \mathrm{~mL} /\left(\mathrm{cm}^{2} \mathrm{~h}\right)$, respectively, and the corrosion rate of AZ61 alloy after solution treatment is $0.0126 \mathrm{~mL} /\left(\mathrm{cm}^{2} \mathrm{~h}\right)$, indicating that the solution treatment can reduce the corrosion rate significantly. In addition, the corrosion rate of AZ61 alloy containing $10 \mathrm{ppm}$ Fe under solution condition is even lower than that of A380 aluminum alloy. The distinction of hydrogen evolution volume is smaller in aged condition than as-cast and solution treatment conditions when the $\mathrm{Fe}$ content is beyond $20 \mathrm{ppm}$. The as-cast alloys have the highest corrosion rate, and the solution treatment had the lowest one, being consistent with other researchers' work [35].

\subsection{Corrosion Morphology}

As seen in Fig. 6, the corroded region decreases with the decrease in Fe content in the as-cast samples and starts from some local points and eventually spreads over the entire sample surface. The macroscopic degree of corrosion is in agreement with the corrosion test. The alloy with low level of Fe has less corrosion area; in contrast, the other alloy with high $\mathrm{Fe}$ content exhibits large corrosion area. In order to investigate the mechanism involved in the corrosion process and the initial stage of localized corrosion, the high magnification images of corrosion surface for the AZ61 alloy with $150 \mathrm{ppm}$ Fe after immersion are presented in Fig. 7.

It is found in Fig. 7 that severe micro-galvanic corrosion has occurred in the Mg matrix, and the corrosion products are distributed along the edge of corrosion hole, instead of covering the corroded areas. This area of localized corrosion of the as-cast specimen indicates that the corrosion initiates closely to the second phases and impurity particles containing iron. Corrosion products, mainly $\mathrm{Mg}$ oxides or hydroxides, are detected around the corrosion pit on the matrix after immersion (Fig. 7d), which is similar to the results reported by Guo et al. [50]. EDS analysis shows that the Fe content of (a)

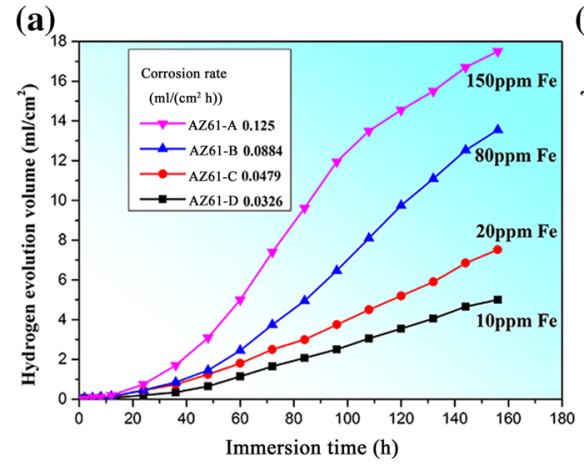

(b)

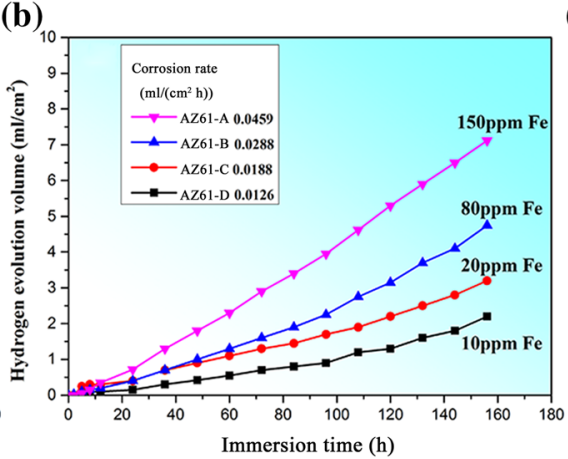

(c)

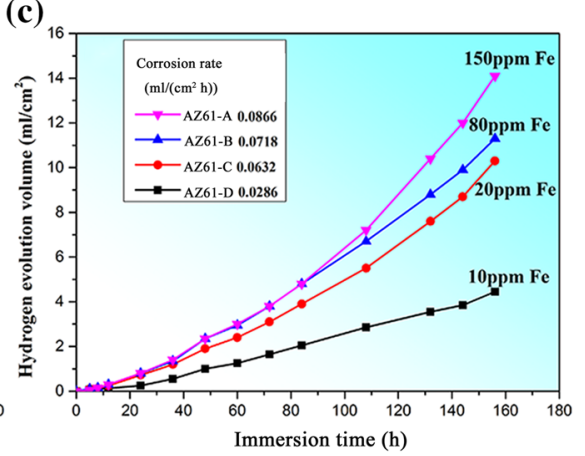

Fig. 5 Corrosion behavior of AZ61 alloys measured in terms of hydrogen evolution: a as-cast, $\mathbf{b}$ solution treatment, $\mathbf{c}$ as-aging 

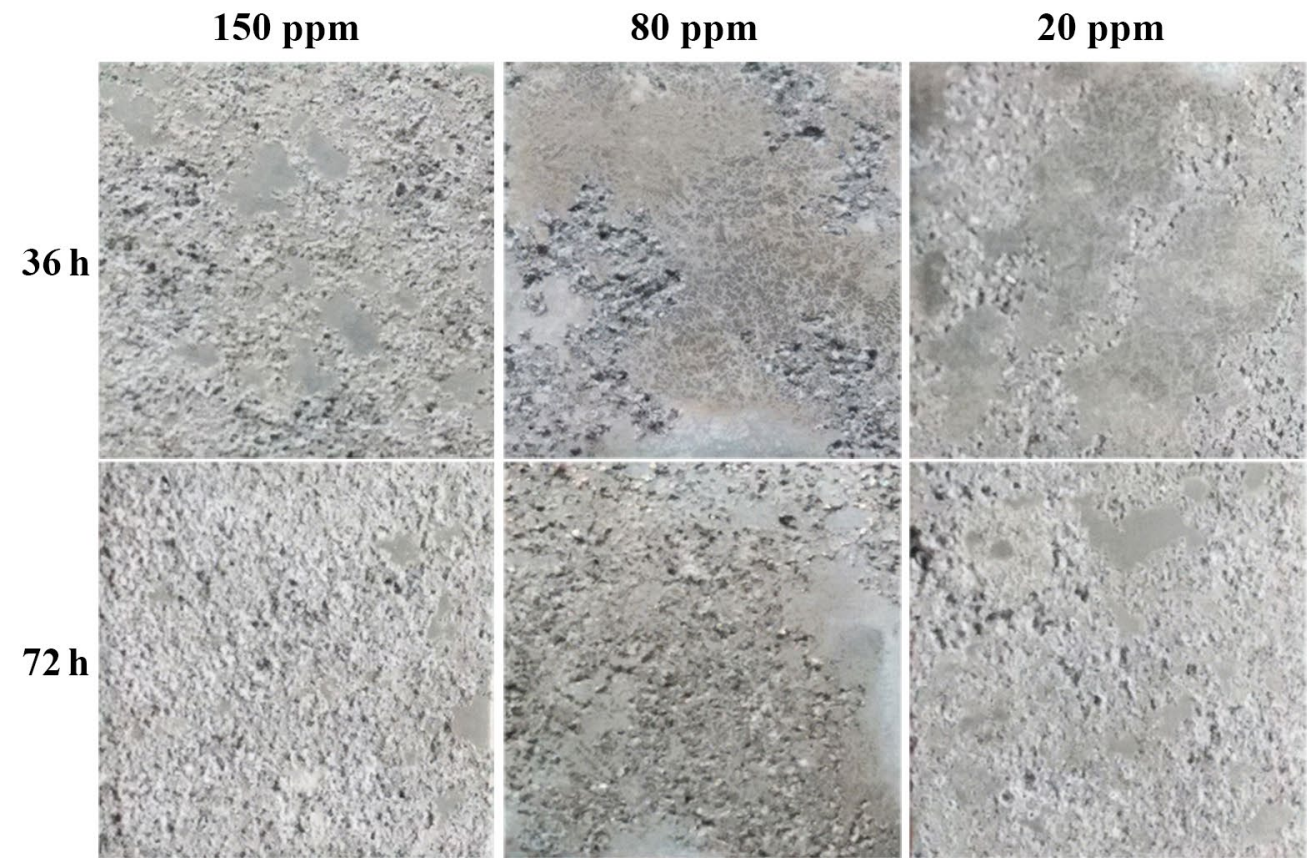

10 ppm

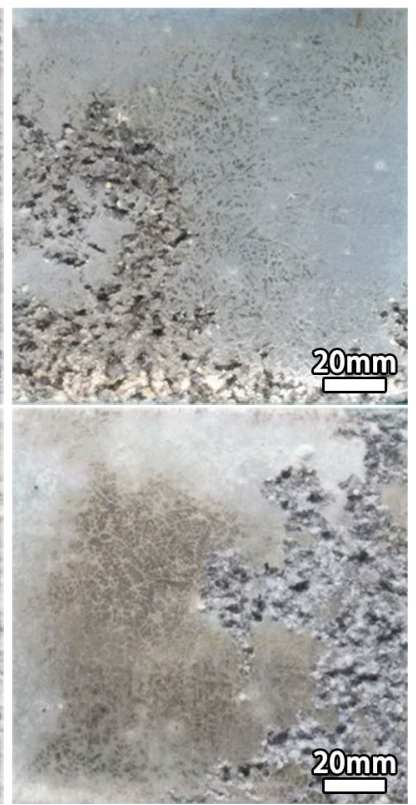

Fig. 6 Macroscopic corrosion morphology of as-cast AZ61 samples

the region next to the corroded area is higher than those corroded areas, which suggests that corrosion is more likely to happen due to the micro-galvanic acceleration of the $\alpha-\mathrm{Mg}$ adjacent to the impurity particles.

\section{Discussion}

Immersion test was used to evaluate the corrosion behavior of AZ61 alloys. The corrosion of magnesium in aqueous environments generally proceeds by electrochemical reaction with water, and the overall reaction of magnesium dissolution is described as follows:

$\mathrm{Mg}+2 \mathrm{H}_{2} \mathrm{O} \rightarrow \mathrm{Mg}(\mathrm{OH})_{2}+\mathrm{H}_{2}$.

The overall reaction can be expressed as the sum of the different partial reactions:

$\mathrm{Mg}_{(\mathrm{s})} \rightarrow \mathrm{Mg}_{(\mathrm{aq})}^{2+}+2 \mathrm{e}^{-} \quad$ (Anodic reaction).

$2 \mathrm{H}_{2} \mathrm{O}+2 \mathrm{e}^{-} \rightarrow \mathrm{H}_{2(\mathrm{~g})}+2 \mathrm{OH}_{(\mathrm{aq})}^{-} \quad$ (Cathodic reaction).

$\mathrm{Mg}_{(\mathrm{aq})}^{2+}+2 \mathrm{OH}_{(\mathrm{aq})}^{-} \rightarrow \mathrm{Mg}(\mathrm{OH})_{2} \quad$ (Product formation).

The cathodic reaction is hydrogen evolution, leading to hydroxide film can covering the surface of $\mathrm{Mg}$. The stability of the hydroxide film is strongly affected by the microstructure. On the surface of the original $\mathrm{Mg}$ matrix,
$\mathrm{MgO}$ film is formed due to exposure to the air [51]; therefore, naturally formed oxide film on pure $\mathrm{Mg}$ suggests the formation of a mixture of $\mathrm{Mg}, \mathrm{MgO}$ and $\mathrm{Mg}(\mathrm{OH})_{2}$. $\mathrm{Mg}$ is a naturally passive metal that easily suffers severe microgalvanic corrosion when contacted to the impurity elements $\mathrm{Fe}, \mathrm{Ni}, \mathrm{Cu}$ and $\mathrm{Co}$ with higher electrode potential (the potential of $\mathrm{Fe}$ is $-0.44 \mathrm{~V}$, the potential of $\mathrm{Mg}$ is $-2.37 \mathrm{~V}$ ), and the corrosion rate increases significantly with increasing impurity element content. Figure 8 illustrates the corrosion process of magnesium alloys containing impurity particles. When the surface of the alloy is exposed to an aqueous solution, $\mathrm{Mg}$ and/or $\mathrm{MgO}$ reacts with water to form $\mathrm{Mg}(\mathrm{OH})_{2}$. This layer, however, is partially protective and is always destroyed, especially in aqueous solutions. The localized corrosion occurred in $\alpha-\mathrm{Mg}$ matrix adjacent to the impurity. Metals with low hydrogen overvoltage, such as $\mathrm{Ni}, \mathrm{Fe}$ and $\mathrm{Cu}$, constitute efficient cathodes for magnesium and cause severe galvanic corrosion [52].

The present work shows that controlling the content of impurity Fe during melting process and heat treatment can effectively improve the corrosion resistance of magnesium alloys. According to the previous literature [32, 53], corrosion rate increases with larger potential difference between anode and cathode. From the above results, it can be concluded that the corrosion process initiates in the vicinity of inclusions with high Fe content and second phases. Fe has extremely deleterious effect due to its low solid solubility limits, and it can serve as active cathodic site. 

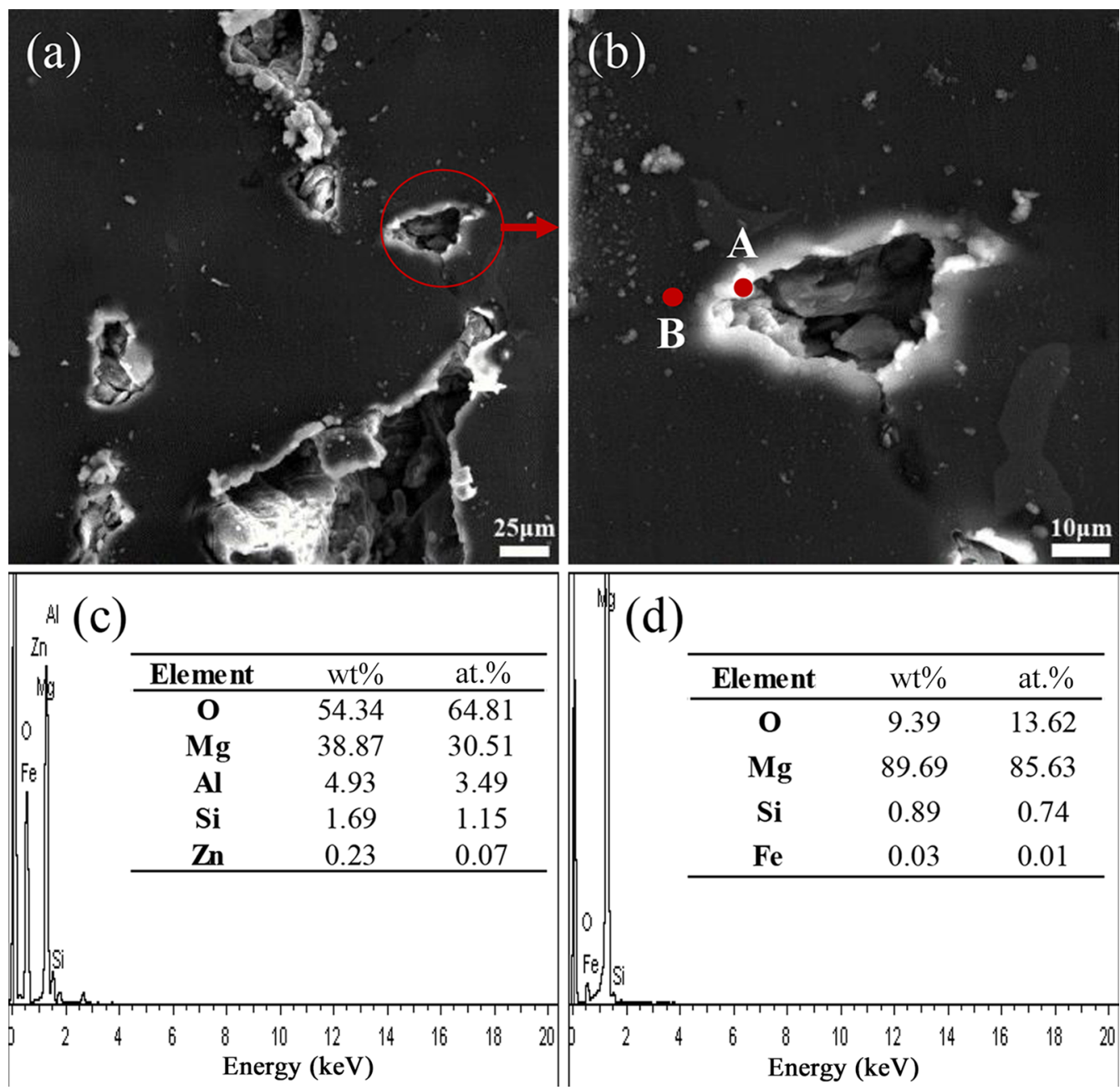

(d)

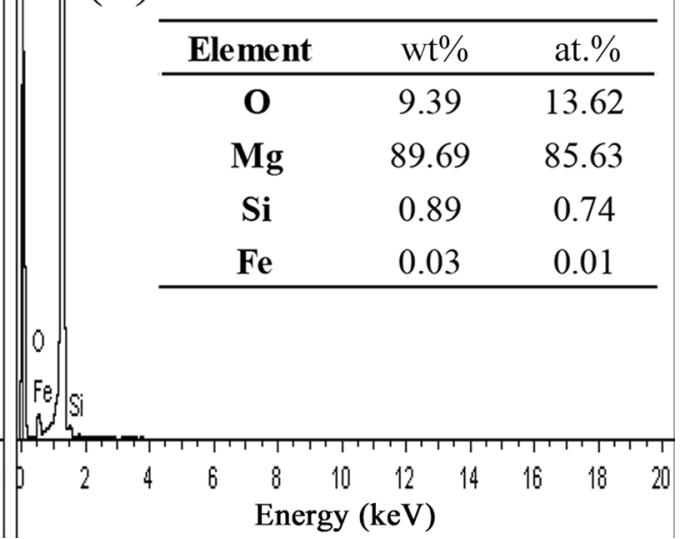

Fig. 7 a SEM image, b partially higher magnification image of corroded surfaces of as-cast AZ61 alloy with 150 ppm Fe, $\mathbf{c}$ and $\mathbf{d}$ represent EDS spectrums collected from points A and B, respectively

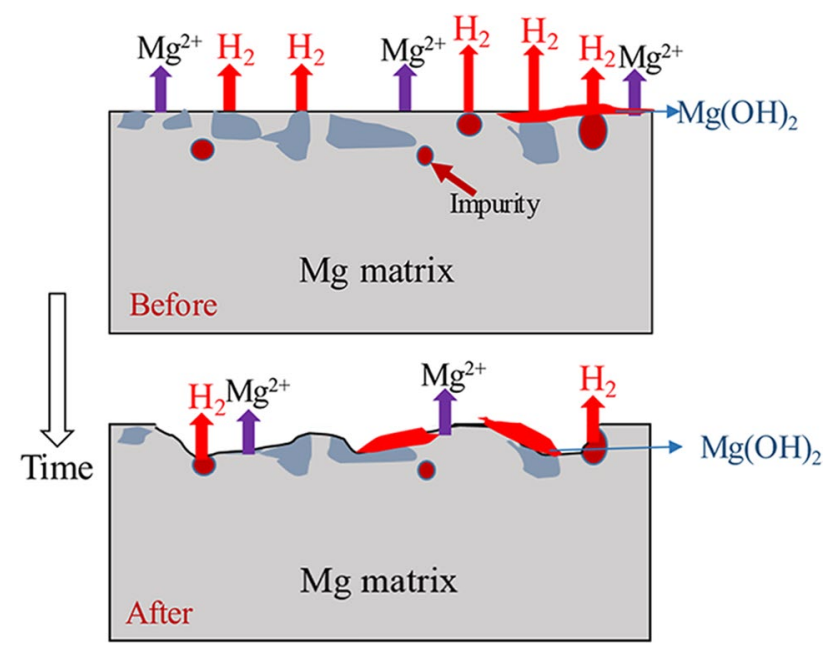

Fig. 8 Schematic presentation of galvanic corrosion of $\mathrm{Mg}$ alloy
The difference in corrosion rates among the cast, solution treatment and aging conditions is related to the quantity of second phases. As shown in Fig. 1, it is composed of $\alpha-\mathrm{Mg}$ and second phases under the cast condition, whereas under the solution treated condition, it almost consists of only $\alpha-\mathrm{Mg}$ phases, with a small quantity of second phases and some impurity clusters in the matrix. Dissolution of the second phase in the $\alpha-\mathrm{Mg}$ matrix results in a decrease in the amount of microgalvanic corrosion between the $\alpha-\mathrm{Mg}$ matrix and the second phase, and the corrosion rate is greatly reduced. The high corrosion rate of aged condition is able to be attributed to the precipitates appearing after aging treatment.

\section{Conclusions}

(1) AZ61 alloys mainly consist of $\alpha-\mathrm{Mg}, \mathrm{Mg}_{17} \mathrm{Al}_{12}$ and $\mathrm{Al}_{8} \mathrm{Mn}_{5}$. The Fe particles are segregated in the $\mathrm{Al}_{8} \mathrm{Mn}_{5}$ phase. The content of impurity element Fe does not 
affect the microstructure and grain size of the AZ61 alloys obviously.

(2) The corrosion rate and corrosion area of AZ61 alloy decreased with decreasing impurity element Fe content in the cast, solution treatment and aged conditions. Solution treatment leads to the lowest corrosion rate. The as-cast AZ61 alloy with $10 \mathrm{ppm}$ Fe exhibits an extremely low corrosion rate of $0.21 \mathrm{~mm} / \mathrm{a}$, which is lower than that of A380 aluminum alloy.

(3) Fe has extremely deleterious effects due to that it can serve as active cathodic site. The Fe impurity reduction results in a decrease in the amount of micro-galvanic corrosion between the $\alpha-\mathrm{Mg}$ matrix and Fe particles, and the corrosion rate is greatly reduced.

Acknowledgements This work was financially supported by the National Key R\&D Program of China (No. 2016YFB0301100), the National Natural Science Foundation of China (No. 51571043) and the Fundamental Research Funds for the Central Universities (Nos. 2018CDJDCL0019, cqu2018CDHB1A08 and 2018CDGFCL0005).

\section{References}

[1] T. Morishige, K. Ueno, M. Okano, T. Goto, E. Nakamura, T. Takenaka, Mater. Trans. 55, 1506 (2014)

[2] M. Rashad, F. Pan, M. Asif, X. Chen, J. Magnes. Alloys 5, 271 (2017)

[3] C. Zhao, X. Chen, F. Pan, J. Wang, S. Gao, T. Tu, C. Liu, J. Yao, A. Atrens, J. Mater. Sci. Technol. 35, 142 (2019)

[4] H. Matsubara, Y. Ichige, K. Fujita, H. Nishiyama, K. Hodouchi, Corros. Sci. 66, 203 (2013)

[5] S. Arthanari, R. Nallaiyan, S.K. Seon, J. Magnes. Alloys 5, 277 (2017)

[6] C. Zhao, X. Chen, F. Pan, S. Gao, D. Zhao, X. Liu, Mater. Sci. Eng. A 713, 244 (2018)

[7] H. Zhao, L.Q. Wang, Y.P. Ren, B. Yang, S. Li, G.W. Qin, Acta Metall. Sin. (Engl. Lett.) 31, 575 (2018)

[8] G.L. Song, A. Atrens, Adv. Eng. Mater. 9, 177 (2007)

[9] S.H. Adsul, K.R.C.S. Raju, B.V. Sarada, S.H. Sonawane, R. Subasri, J. Magnes. Alloys 6, 299 (2018)

[10] L.X. Wang, R.B. Song, C.H. Cai, J.Y. Li, Acta Metall. Sin. (Engl. Lett.) 32, 10 (2019)

[11] G. Song, B. Johannesson, S. Hapugoda, D. St. John, Corros. Sci. 46, 955 (2004)

[12] G. Song, D. St. John, Corros. Sci. 46, 1381 (2004)

[13] Y. Zhang, C. Yan, F. Wang, W. Li, Corros. Sci. 47, 2816 (2005)

[14] J. Moscovici, M. Benzakour, S. Decker, C. Carnes, K. Klabunde, A. Michalowicz, J. Synchrotron Radiat. 8, 925 (2001)

[15] T. Zheng, Y. Hu, S. Yang, J. Magnes. Alloys 5, 404 (2017)

[16] M. Liu, P.J. Uggowitzer, P. Schmutz, A. Atrens, JOM 60, 39 (2008)

[17] H.R. Bakhsheshi-Rad, E. Hamzah, R. Ebrahimi-Kahrizsangi, M. Daroonparvar, M. Medraj, Vacuum 125, 185 (2016)

[18] B.J. Wang, J.Y. Luan, D.K. Xu, J. Sun, C.Q. Li, E.H. Han, Acta Metall. Sin. (Engl. Lett.) 32, 1 (2019)
[19] G.L. Makar, J. Kruger, Int. Mater. Rev. 38, 138 (1993)

[20] G. Song, Adv. Eng. Mater. 7, 563 (2005)

[21] M.C. Zhao, M. Liu, G.L. Song, A. Atrens, Adv. Eng. Mater. 10, $93(2008)$

[22] G. Song, A. Atrens, Adv. Eng. Mater. 5, 837 (2003)

[23] M. Inoue, M. Iwai, K. Matuzawa, S. Kamado, Y. Kojima, J. Jpn. Inst. Light Met. 48, 257 (1998)

[24] M.C. Zhao, M. Liu, A. Atrens, Adv. Eng. Mater. 10, 104 (2008)

[25] M. Zhao, M. Liu, G. Song, A. Atrens, Corros. Sci. 50, 1939 (2008)

[26] M. Zhao, L. Ming, G. Song, A. Atrens, Corros. Sci. 50, 3168 (2008)

[27] G. Song, A. Atrens, D.S. John, X. Wu, J. Nairn, Corros. Sci. 39, 1981 (1997)

[28] L. Yang, X. Zhou, S.M. Liang, R. Schmid-Fetzer, Z. Fan, G. Scamans, J. Robson, G. Thompson, J. Alloys Compd. 619, 396 (2015)

[29] N.I.Z. Abidin, D. Martin, A. Atrens, Corros. Sci. 53, 862 (2011)

[30] Z. Qiao, Z. Shi, N. Hort, N.I.Z. Abidin, A. Atrens, Corros. Sci. 61, $185(2012)$

[31] F. Cao, Z. Shi, J. Hofstetter, P.J. Uggowitzer, G. Song, M. Liu, A. Atrens, Corros. Sci. 75, 78 (2013)

[32] A. Atrens, G.L. Song, M. Liu, Z. Shi, F. Cao, M.S. Dargusch, Adv. Eng. Mater. 17, 400 (2015)

[33] M. Liu, P.J. Uggowitzer, A.V. Nagasekhar, P. Schmutz, M. Easton, G.L. Song, A. Atrens, Corros. Sci. 51, 602 (2009)

[34] Y. Wang, Foundry 50, 61 (2001)

[35] L. Peng, J. Chang, X. Guo, A. Atrens, W. Ding, Y. Peng, J. Appl. Electrochem. 39, 913 (2009)

[36] N.D. Nam, M.Z. Bian, M. Forsyth, M. Seter, M. Tan, K.S. Shin, Corros. Sci. 64, 263 (2012)

[37] Z. Pu, G.L. Song, S. Yang, J.C. Outeiro, O.W.D. Jr, D.A. Puleo, I.S. Jawahir, Corros. Sci. 57, 192 (2012)

[38] G. Song, A. Atrens, M. Dargusch, Corros. Sci. 41, 249 (1998)

[39] G. Song, A.L. Bowles, D.H. Stjohn, Mater. Sci. Eng. A 366, 74 (2004)

[40] D. Eliezer, P. Uzan, E. Aghion, in Magnesium Alloys 2000, ed. by Y. Kojima, T. Aizawa, K. Higashi, S. Kamado, Materials Science Forum, Osaka, 27-30 Jan 2003

[41] F. Pan, X. Chen, T. Yan, T. Liu, J. Mao, W. Luo, Q. Wang, J. Peng, A. Tang, B. Jiang, J. Magnes. Alloys 4, 8 (2016)

[42] F. Pan, M. Yang, X. Chen, J. Mater. Sci. Technol. 32, 1211 (2016)

[43] Pandat is a software package for calculating phase diagrams and thermodynamic properties of multi-component alloys. CompuTherm LLC. http://www.computherm.com/index.php?route =common/home (2018)

[44] Z. Shi, A. Atrens, Corros. Sci. 53, 226 (2011)

[45] A. Pardo, M.C. Merino, A.E. Coy, R. Arrabal, F. Viejo, E. Matykina, Corros. Sci. 50, 823 (2008)

[46] X. Zhou, Y. Huang, Z. Wei, Q. Chen, F. Gan, Corros. Sci. 48, $4223(2006)$

[47] J.I. Kim, H.N. Nguyen, B.S. You, Y. Kim, Scr. Mater. 162, 355 (2019)

[48] R. Ambat, N. Aung, W. Zhou, Corros. Sci. 42, 1433 (2000)

[49] M.M. Avedesian, H. Baker, Magnesium and Magnesium Alloys ASM Specialty Handbook (ASM International, Ohio, 1999), pp. $56-77$

[50] X. Guo, J. Chang, S. He, W. Ding, X. Wang, Electrochim. Acta 52, 2570 (2007)

[51] J.H. Nordlien, S. Ono, N. Masuko, K. Nisancioglu, Corros. Sci. 39, 1397 (1997)

[52] G.L. Song, A. Atrens, Adv. Eng. Mater. 1, 11 (1999)

[53] G.L. Song, Z. Xu, Corros. Sci. 54, 97 (2012) 